\title{
ESTABLISHING AND MAINTAINING MENTORING RELATIONSHIPS: AN OVERVIEW OF MENTOR AND MENTEE COMPETENCIES
}

\author{
DAVID CLUTTERBUCK \\ Sheffield Hallam University \\ United Kingdom
}

\begin{abstract}
This introduction to this special edition of the SA Journal of Human Resource Management dealing with recent qualitative and quantitative work undertaken by South African Human Resource Practitioners and Industrial Psychologists on the topic of mentoring, attempts to draw together the thinking around the nature and concept of mentor and mentee competence. A framework of competencies which mentors and mentees can be helped to develop before or during their mentoring relationships is also suggested. Although the proposed competencies described have face validity, there is still a great deal of research to be done to establish the validity using more rigorous measures.
\end{abstract}

\section{OPSOMMING}

Hierdie inleiding tot die spesiale uitgawe van die SA Tydskrif vir Menslikehulpbronbestuur wat handel oor kwalitatiewe en kwantitatiewe studies wat deur Suid-Afrikaanse Menslikehulpbronpraktisyns en Bedryfsielkundiges oor die onderwerp mentorskap onderneem is, poog om die gedagtegang rondom die aard van die konsep mentor en mentee bevoegdheid bymekaar te bring. Daar word ook 'n raamwerk van praktiese bevoegdhede wat mentors en mentees kan ontwikkel voor of tydens die mentorverhouding voorgestel. Alhoewel die voorgestelde bevoegdhede gesigsgeldigheid het, is daar nog 'n behoefte aan heelwat navorsing wat van meer indringende metings gebruik maak om die geldigheid daarvan te bepaal.

Relational learning at work has become prominent in a workplace characterised by uncertainty, change and ambiguity. Indeed, the more turbulent and difficult conditions become in today's work settings, the more naturally occurring work challenges there are, and the more motivated people are to give and receive help. Relationships are a major source of learning. People do much of their learning through connection with other people. However, individuals are more likely to engage in successful developmental relationships at work when they have both the desire and competence to do so (Hall \& Kahn, 2002).

The most powerful learning is often provided by the mentormentee relationship which provides both task learning and socio-emotional learning. Creating an effective mentor-mentee relationship requires the competence to create increasingly trust-worthy settings. For mentors, this means performing appropriate care-giving functions which allow mentees to experience themselves as valued and supported (Kahn, 1993). For their part, mentees need to know how to make themselves increasingly visible. They must disclose themselves-what they are thinking, feeling, perceiving-in the course of seeking support and guidance (Hall \& Kahn, 2002; Kram, 1996).

The focus of this article is on developmental mentoring (Clutterbuck, 2001; Clutterbuck \& Sweeney, 2003; Hay, 1995; Klasen \& Clutterbuck, 2002). Developmental mentoring is defined as offline help by one person to another in making significant transitions in knowledge, work, or thinking (Clutterbuck, 2001, p. 3). This definition of mentoring is the official definition of the European Mentoring Centre. A weakness of the academic literature is the lack of longitudinal research on mentor and mentee competencies. Although it is logical that the competencies required of a mentor and a mentee would evolve with the progress of the relationship, there has been no systematic examination of the process (Clutterbuck \& Lane, 2005).

Furthermore, a set of standards for mentoring programmes has been generated and subjected to public consultation on behalf of the European Mentoring and Coaching Council. Standards

Requests for copies should be addressed to: M Coetzee, coetzm1@unisa.ac.za codify competencies into a framework that can be used to assess how well an individual performs against them. The virtue of this framework is that it provides a structure upon which evidence of competence can be gathered, in terms of both knowledge and effective practice. Unlike most qualification-based programmes, they provide an objective, independent measure. How useful that measure is depends on how credible the standards are perceived to be by programme participants and organisations using mentoring. It is probably fair to say that the jury is still out on this issue.

There does, however, seem to be room for a generic or core set of mentoring standards, which will apply with minimal adaptation to most or all situations and to which situationspecific competencies can be added as appropriate. One valiant attempt to do this is the Draft Occupational Standards on Mentoring, produced by the University of North London, in association with a variety of other academic and practitioner bodies. This was evaluated in over 300 mentoring schemes in all sectors of education, government and business (Clutterbuck, \& Lane, 2005).

The issue of standards in mentoring has arisen for two reasons. First, the rapid spread of mentoring programmes aimed at young and vulnerable people requires close attention to risk management, and Government-supported programmes require standards as an element of impact measurement. Second, the rapid growth of executive coaching and mentoring inevitably gives rise to calls for regulation, given that anyone can claim to have the necessary skills and experience. The increasing volume of qualifications offered in coaching and mentoring does not necessarily help, as they tend not to be specific about the level of competence required (length of experience does not equate to quality of performance!), nor about the audience specific factors that may demand additional competencies (for example, knowledge of cognitive development and skills in behaviour management for mentors of children and persons with special needs.)

The starting point for this article is the captured experience of thousands of mentors, mentees and would-be mentors around the world, who have attended skills development workshops and 
seminars over the past decade, captured on flip charts and in discussion groups. The behavioural dimensions which define the conceptual models of mentor competence presented in this article are based on the experience of the respondents. This is, therefore, a practitioner's account. In addition, however, the article presents some of the research and connections with academic study that reinforce and/or complement these practitioner insights.

The definition of 'competence' is also not always consistent. Is a competent individual one who can do the basics of a task consistently well? Or someone who is expert at it? Is competence solely a matter of skill and application, or does it also include personality and attitude? For the purposes of this article, competence is defined as the consistent, observable and measurable ability to perform a defined task or an element of a task (Ackley \& Gall, 1992; Clutterbuck \& Lane, 2005; Lane, 1996; 1997). The development of a fully validated set of competencies is a lengthy and time-consuming business. The concepts outlined here can best be described as protocompetencies - skills and behaviours which have high face validity, but have not so far been subjected to rigorous validation (Clutterbuck \& Lane, 2005).

\section{Mentor competence}

Defining mentor competencies is also complicated by the fact that all mentoring relationships are both situational and temporal in nature. Situational refers to the primary responsibility of the mentor to respond to the mentee's need. This is a bold statement to make, but it is one that is generally endorsed by all parties in a mentoring programme, both participants and the organisation. If there are different needs, it implies that there should be different responses. We can therefore infer that one of the generic competencies of a mentor is to be able to respond appropriately to the variety of needs a mentor may have (Clutterbuck \& Lane, 2005). This immediately poses problems, because the range of situations could be very wide.

Let us peel this onion one layer further. Situation may also be affected by purpose. Whose purpose? Typically the organisation will have a scheme purpose, which provides the reason for supporting mentoring. This purpose might be developing top talent, promoting diversity, retaining graduate recruits and so on. At the same time, the participants in the relationship will have a common purpose, which may be different from that of the organisation. (The mentee may, for example, plan to leave the organisation in three years time.) The mentor may also have some learning goals from the relationship - perhaps to hone his or her skills in developing direct reports. So another generic competence may be the ability to recognise and reconcile different and perhaps conflicting purposes.

The temporal nature of mentoring refers to the way, in which relationships evolve over time. Kathy Kram, whose original and insightful studies of mentoring in the early 1980s have been the foundation for so much later research, identified four phases of evolution: initiation, cultivation, separation and redefinition (Kram, 1983). Field experience with much larger numbers than Kram's original sample suggest potentially five phases that characterise the developmental relationship, namely (1) rapport-building, (2) the direction-setting phase, (3) progress-making, (4) winding down, and (5) moving on or professional relationship.

\section{Phase 1: Rapport-building}

Rapport-building is the initial phase, in which mentor and mentee decide whether or not they want to work with each other. If the chemistry is not right, or there is an inappropriate balance of similarity (common ground, common interests) and dissimilarity (an experience gap that provides opportunities for learning), the relationship will not progress very far under its own steam. As important as the skills of achieving rapport is the ability of the mentor to recognise a lack of rapport and manage it positively - confronting the issue openly and reviewing with the mentee what kind of person might better meet their needs. At this stage, also, mentor and mentee negotiate how the relationship will be conducted - what each expects of the other, particularly in terms of behaviour (Hay, 1995; Ibarra, 2000; Klasen \& Clutterbuck, 2002).

\section{Phase 2: Direction-setting phase}

The direction-setting phase is where mentor and mentee achieve clarity about what each aims to achieve from the relationship and how. For example, clear development targets may be set for the mentee to achieve. Goals may change with circumstances or as they are achieved and replaced with new ones. However, having a sense of purpose for the relationship is fundamental to achieving commitment to it.

\section{Phase 3: Progress-making}

Progress-making is the hard core of the mentoring relationship where most of the time and energy is expended. Having helped the mentee to define and commit to personal change, the mentor has to guide and support them as needed. Most of this effort will take place within the mentoring meetings, but much may also occur through telephone conversations and via e-mail. The portfolio of potential skills required here is as wide as the variety of potential applications of mentoring. Where practical and within the role, the mentor will wish to provide the particular type of help that is needed, when it is asked for.

\section{Phase 4: Winding down}

Winding down occurs as the relationship has delivered or helped to deliver the desired outcomes, or when the mentee begins to outgrow the mentor. It is not always obvious when the time has come for the mentee to leave the comfort of the mentoring nest. The mentor needs to be sensitive to this issue and to some extent pre-emptive, reviewing the value-added of the relationship with the mentee from time to time. Having a vision of where the relationship might go (although not one that restricts or restrains its potential by being too fixed or too narrow) also helps the mentor plan towards an effective, positive ending (Clutterbuck \& Megginson, 2001).

\section{Phase 5: Moving on/professional friendship}

Moving on from a mentoring relationship into a less committed, more casual relationship, or professional friendship demands potential complex skills of redefinition. These have been likened to changes in relationship between parent and child. Some such relationships never progress beyond parent-child behaviours, even when the child has grown up and become a parent in turn. Old habits die hard. Other parent-child relationships dissolve into conflict: instead of dependence, the child's need to self-express leads to counter-dependence - a rejection of the parent. In a healthy relationship, however, the child achieves independence and their interaction with the parent becomes collegial (Clutterbuck \& Lane, 2005; Hay, 1995; Kiohnen \& John, 1998). The greater the element of sponsorship and power broking within a relationship, the more difficult it appears to be for both parties to achieve the positive independence of each other that underlies a continuing professional friendship (Clutterbuck, 1998; Clutterbuck \& Megginson, 2001; Hay, 1995).

Each phase requires a modification of the mentor's behaviours and, by inference therefore, of the competences required. The skills of rapport building differ substantially from those required in helping someone clarify and commit to specific career or personal development goals. The skills required in managing a relationship which has settled into an effective routine are different from those required in bringing the formal phase of the relationship to a positive close. And, should the relationship involve into more of a long-term supportive 
friendship, it may call for different behaviours again. Another generic competence, therefore, may be recognising and adapting appropriately to the phases of the mentoring relationship (Clutterbuck, 1998; Hay, 1995; Kram, 1985). Table 1 provides an overview of some suggested mentor competencies for each phase of the mentoring relationship.

\section{TABle 1}

SOME SUGGESTED MENTOR COMPETENCIES FOR EACH PHASE OF THE MENTORING RELATIONSHIP (CLUTTERbuCK \& LANE, 2005)

\begin{tabular}{|c|c|}
\hline $\begin{array}{l}\text { Mentorship relationship } \\
\text { phase }\end{array}$ & Suggested competence \\
\hline Building rapport & $\begin{array}{l}\text { Active listening } \\
\text { Empathising } \\
\text { Giving positive regard } \\
\text { Offering openness and trust to elicit reciprocal } \\
\text { behaviour } \\
\text { Identifying and valuing both common ground } \\
\text { and differences }\end{array}$ \\
\hline Setting direction & $\begin{array}{l}\text { Goal identification, clarification and management } \\
\text { Personal project planning } \\
\text { Testing mentee's level of commitment to specific } \\
\text { goals } \\
\text { Reality testing-helping the mentee focus on a } \\
\text { few, achievable goals rather than on many } \\
\text { pipedreams }\end{array}$ \\
\hline Progression & $\begin{array}{l}\text { Sustaining commitmentEnsuring sufficient } \\
\text { challenge in the mentoring dialogue } \\
\text { Helping the mentee take increasing responsibility } \\
\text { for managing the relationship } \\
\text { Being available and understanding in helping the } \\
\text { mentee cope with set-backs }\end{array}$ \\
\hline $\begin{array}{l}\text { Winding down } \\
\text { Professional friendship }\end{array}$ & $\begin{array}{l}\text { Manage the dissolution process } \\
\text { Ability to redefine the relationship when it has } \\
\text { run its formal course }\end{array}$ \\
\hline
\end{tabular}

Generic mentor competencies

Fieldwork suggests that in addition to proto-competencies, there are also generic competencies (Clutterbuck, 2001; Clutterbuck \& Megginson, 2001; Clutterbuck \& Lane, 2005). Several years ago, Clutterbuck \& Lane (2005) began to gather perceptions of managers, professional executive mentors and human resource professionals about those behaviours and abilities, which had proven most useful in executive mentoring. In parallel, they gathered feedback from initial training sessions, review workshops and questionnaires to both programme participants and programme coordinators for a variety of other work-based programmes - for equal opportunities, graduate induction, succession planning and so on - across a wide array of industries and nationalities.

The research method was highly informal. In the initial training workshop mentors and mentees were asked to complete a list of the characteristics that they would least expect in an effective mentor - 'the mentor from hell' - then in an effective mentor.

Clutterbuck \& Lane (2005) found five pairs of matched capabilities, which were commonly associated with the most efficacious mentors. These were:

- Self-awareness and behavioural awareness (understanding others)

- Business/professional savvy and sense of proportion

- Communication and conceptual modelling

- Commitment to own learning and interest in helping others to learn

- Relationship management and goal clarity

Self-awareness and behavioural awareness (understanding others) This might more easily be expressed as 'mentors need a relatively high level of emotional intelligence', although only two elements of emotional intelligence are represented here
(Goleman, 1996). Mentors need high self-awareness in order to recognise and manage their own behaviours within the helping relationship and to use empathy appropriately. Selfawareness helps them recognise when there is a dissonance between what they are advising the mentee to do and what they do themselves. It is also essential to the processes of analysing one's own behaviour and motivations. One of the common problems we find in mentoring relationships is that the mentor sees the mentee's issues in the light of the mentor's own problems and preoccupations, rather than from the mentee's perspective. Such transference may lead to inappropriate guidance.

Given that the mentor's role is often at least in part to help the mentee grow his or her own self-awareness, being an effective role model for self-perceptiveness could be regarded as an essential skill. By the same token, having an understanding of, as well as insight into other people's behaviour and motivations is equally important. To help others manage their relationships, the mentor must have reasonably good insight into patterns of behaviour between individuals and groups of people. Predicting the consequences of specific behaviours or courses of action is one of the many practical applications of this insight. It is not typically essential for the mentor to have a deep understanding of behavioural psychology, but it does help for them to be able to relate issues to some of the basic concepts of motivation, social exchange and learning processes. Helping someone else work through such issues frequently results in the mentor reflecting more deeply on similar issues of their own. The ability to pose the right questions at the right time is therefore an essential competence of mentors. Some of the questions, which mentors may usefully ask themselves and their mentees to build selfawareness are summarised in Table 2.

TABLE 2

TYPES OF QUESTIONS USED IN MENTORING (Klasen \& Clutterbuck, 2002:158)

\begin{tabular}{lll}
\hline Type of question & Aim of question & Examples \\
\hline Reflective & $\begin{array}{l}\text { Get mentee to say more } \\
\text { about an issue and to } \\
\text { explore it in more depth }\end{array}$ & $\begin{array}{l}\text { "You said ... can you explain } \\
\text { in more detail how you } \\
\text { mean this?" }\end{array}$ \\
Hypothetical & $\begin{array}{l}\text { Introduction of new ideas } \\
\text { on part of mentor; making } \\
\text { suggestions }\end{array}$ & "What about...?" \\
Justifying & $\begin{array}{l}\text { Obtaining further } \\
\text { information on reasons, } \\
\text { attitudes, feelings }\end{array}$ & $\begin{array}{l}\text { "Can you elaborate on what think that?" } \\
\text { mabing }\end{array}$ \\
$\begin{array}{l}\text { Discovering motivations, } \\
\text { feelings and hidden } \\
\text { concerns }\end{array}$ & $\begin{array}{l}\text { "What would you perceive } \\
\text { as the cause of this?" }\end{array}$ \\
& $\begin{array}{l}\text { "When did you first } \\
\text { Establishing whether the } \\
\text { mentee has understood } \\
\text { clearly }\end{array}$ & $\begin{array}{l}\text { "Are you sure about that?" } \\
\text { "Why do you feel this }\end{array}$ \\
\hline
\end{tabular}

Business/professional savvy and sense of proportion

Savvy is the intuitive wisdom a person gathers from extensive and varied experience and reflection on that experience. It could also be referred to as specific contextual knowledge. The mentee's need for access to that wisdom may be very broad (an overview of good business practice) or quite narrow (making better use of a computer). Savvy may be technical, strategic, political or systemic. It helps the mentee avoid problems, which they might not have foreseen; find better strategies for getting around obstacles; and it is the source of those 'killer' questions that force people to reshape their thinking. In short, savvy is the link between experience and being able to use experience to guide another person effectively (Hay, 1995; Clutterbuck \& Lane, 2005). 
Sense of proportion (wider contextual experience) is a broader perspective that places the organisation's goals and culture in the wider social and business context. It is, in effect, the other side of wisdom - the ability to step back from the detail, to identify what is really important and to link together apparently discrete issues. It also encompasses the ability to project good humour, helping the mentee recognise the elements of incongruity in situations, to laugh at himself or herself, where appropriate. Mentees frequently find this to be one of the most valuable competencies of a mentor - very often the mentee is so close to his or her issues, that they cannot easily put them into perspective without skilled help.

\section{Communication and conceptual modelling}

Communication is not a single skill, but rather a combination of a number of skills. Those most important for mentors include:

- Listening - opening the mind to what the other person is saying, demonstrating interest/attention, encouraging them to speak, holding back on filling the silences.

- Observing as receiver - being open to the visual and other non-verbal signals, recognising what is not said.

- Parallel processing - analysing what the other person is saying, reflecting on it, preparing responses. Effective communicators do all of these in parallel, slowing down the dialogue as needed to ensure that they do not overemphasise preparing responses at the expense of analysis and reflection. Equally, they avoid becoming so mired in their internal thoughts that they respond inadequately or too slowly.

- Projecting - crafting words and their emotional 'wrapping' in a manner appropriate for the situation and the recipient(s)

- Observing as projector - being open to the visual and other non-verbal signals, as clues to what the recipient is hearing/understanding; adapting tone, volume, pace and language appropriately.

- Exiting - concluding a dialogue or segment of dialogue with clarity and alignment of understanding (ensuring message received in both directions) and agreeing on follow-up action to be taken.

The most effective mentors place far more emphasis on listening and encouraging the mentee to speak than on talking themselves. They are also adept at the use of silence, at times suggesting the mentee pause to reflect on an issue; at other times simply allowing silence to take over, giving the mentee space to think matters through. Effective mentors have a portfolio of models they can draw upon to help the mentee understand the issues they face. These models can be selfgenerated (i.e. the result of personal experience), drawn from elsewhere (e.g. models of company structure, interpersonal behaviours, strategic planning, career planning) or - at the highest level of competence - generated on the spot as an immediate response. According to the situation and the learning styles of the mentee, it may be appropriate to present these models in verbal or visual form. Or the mentor may not present them at all, but simply use them as the framework for asking penetrating questions.

\section{Commitment to own learning and interest in helping} others to learn

Effective developmental mentors become role models for selfmanaged learning. They seize opportunities to experiment and take part in new experiences. They read widely and are reasonably efficient at setting and following personal development plans. They actively seek and use behavioural feedback from others. Within the context of the mentoring relationship, they perceive this as a significant opportunity for mutual learning. They may articulate their learning needs to the mentee and from time to time share what they have learned from the relationship.

At the same time, effective mentors have an innate interest in achieving through others and in helping others recognize and achieve their potential. This instinctive response is important in establishing and maintaining rapport and in enthusing the mentee, building his or her confidence in what they could become. There is a danger here, however. The more the relationship is driven by the mentor's need to feel useful, the easier it is to overshadow the mentee's need to achieve independence. Mentors (particularly in a sponsorship-based model) may end up trying to relive their own careers through someone else. Altruism can be a highly self-serving attitude of mind, if it is not moderated by a sense of social exchange. The overt recognition of mutual learning objectives largely overcomes this problem.

\section{Relationship management and goal clarity}

Both of these areas have been largely covered in the analysis of the various phases of a mentoring relationship. Among the key abilities in relationship management are to establish and maintain rapport, to set and adhere to a schedule of meetings, and to step back and review the relationship from time to time. Mentees rate their mentors highly on relationship management when the latter clearly place an importance on the relationship and demonstrate that they have continued to think about the mentee's issues between meetings.

Goal clarity is important, because the mentor must be able to help the learner sort out what he or she wants to achieve and why. Goal clarity appears to derive from a mixture of skills including systematic analysis and decisiveness. Mentors, who lack the skills to set and pursue clear goals of their own, are likely to struggle to help someone else. Yet most mentors seem to find that helping someone else achieve goal clarity has a positive effect on how they perceive and work towards their own goals.

\section{Macro versus micro mentor competencies}

As Table 3 illustrates, the multiple approaches to identifying the competencies of a mentor give rise to a long list, with considerable duplication. From a practitioner perspective, and/or from the perspective of someone who helps mentors and mentees equip themselves with the skills for the role, this is not necessarily a problem. We know that this is a complex, intuitive, multi-skilled role that requires a very wide spectrum of life skills and purpose-specific skills. The reduction of the list into macro and micro is to some extent arbitrary, but all the items listed under macro-competencies are generic - they are essential for effective role management in all mentoring relationships. The micro elements, by contrast, all have some aspects of situationality - they are specific to a phase of the relationship, or they are a constituent behaviour or skill, which will enhance the relationship, but not necessarily one that all relationship will require in significant measure. Very few mentors out of a potential population are likely to be excellent in all of these micro-competencies - indeed, they may use the mentoring relationship as one means to develop in those areas, where they are least strong. Recognising the ideal, however, provides a platform for development, which both individuals and mentoring scheme coordinators can use.

\section{Mentee competence}

As noted earlier, creating an effective mentor-mentee relationship requires the competence of both mentors and mentees. For the mentee, the ability to capture the mentor's interest and commitment is the precursor to rapport between mentor and mentee, which is in turn crucial to the subsequent maintenance of the relationship. Kram (1983) describes the protégé or mentee as a young manager, who "quickly comes to represent someone with potential, someone who is "coachable" and someone who is enjoyable to work with'. The successful protégé is likely to exhibit more masculine traits, regardless of gender, than feminine traits, according to a study of 387 university professors and their mentoring relationships. The proposed explanation for this result is that 'masculine and/or 
androgynous behaviour is associated with effective leadership and management' - in other words, mentors are drawn to people who most closely match the mentor's perception of potential future leaders.

\section{TABLE 3}

\section{MACRO AND MICRO MENTOR COMPETENCIES} (Clutterbuck \& Lane, 2005)

\section{Macro-competencies}

- To be able to respond appropriately to the variety of needs a mentor may have to recognise and reconcile different and perhaps conflicting purposes.

- Recognising and adapting appropriately to the phases of the mentoring relationship.

- Responding to the learner's needs with the appropriate level of directiveness and the appropriate balance of stretch and nurture.

- Recognising different developmental roles, and having the flexibility to move between roles appropriately and comfortably.

- Recognising the boundaries between mentoring and those elements of other roles which are not normally part of the mentoring experience.

- Establishing a positive, dynamic atmosphere within the relationship (motivational skills).

\section{Micro-competencies}

- Building rapport - active listening, empathising and giving positive regard; offering openness and trust to elicit reciprocal behaviour; identifying and valuing both common ground and differences.

- Setting direction - goal identification, clarification and management; personal project planning; testing the mentee's level of commitment to specific goals; reality testing.

- Progression - sustaining commitment; ensuring sufficient challenge in the mentoring dialogue; helping the mentee take increasing responsibility for managing the relationship; being available and understanding in helping the mentee cope with setbacks.

- Winding down - the ability to review the relationship formally and celebrate what has been achieved.

- Professional friendship - the ability to redefine the relationship when it has run its formal course.

- Self-awareness.

- Behavioural awareness.

- Business/professional savvy.

- Sense of proportion.

- Communication.

- Conceptual modelling.

- Commitment to own learning (being a role model for good practice in self-development).

- Interest in helping others to learn.

- Relationship management.

- Goal clarity.

Kalbfleisch and Davies (1993) summarise the research on receipt of mentoring. A variety of studies suggests that 'demographic factors such as gender (Daniels \& Logan 1983; Ragins 1989; Sands, Parson \& Duane, 1991) and race (Kalbfleisch \& Davies, 1991) may predict the likelihood of having a mentor.' However, O'neill (2001) in summarising the evidence on these issues concludes that the majority of studies do not indicate significant differences on race or gender grounds for receipt of mentoring.

Kalbfleisch and Davies' (1991) analysis is more useful, however, where it examines factors such as communication competence and self-esteem in the mentee, both of which they found to be related to participation in mentoring relationships. They quote Wiemann (1977) who defines communication competence as the ability of an interactant to choose among available communicative behaviours in order that he may successfully accomplish his own goals during an encounter, while maintaining the face and line of his fellow interactants within the constraints of the situation. Among definitions of self-esteem is that it is composed of perceptions of self-worth and perceptions of power and ability. Self-worth originates from a sense of social approval and perceptions of power and ability arise from feelings of effectiveness (Franks \& Marolla, 1976). competence and self-esteem is perceived risk in intimacy.
Mentors and mentees may need to expose their own feelings and hidden experiences, in order to encourage the other party to reciprocate. Kram (1985) and Bullis and Bach (1989) both refer to psychological intimacy as an element of mentoring relationships. The primary conclusions of Kalbfleisch and Davies' study are that: "individuals with higher degrees of communication competence and self esteem, who perceive less risk in intimacy, are more likely to participate in mentoring relationships ... Conversely ... individuals, who may very much need mentoring relationships may not be as likely to be involved in those relationship as individuals who are more communicatively competent, have higher self esteem and perceive less risk in being intimate.' Studies of self-efficacy (Bandura, 1982) also support the position that confident, competent people find relationship building easier than less confident, less competent peers.

Fagenson (1992) studied the needs of mentees and nonmentees for power, achievement, autonomy and affiliation. She found that people who became mentees tended to have higher needs for power and achievement, but not for autonomy and affiliation. It should be noted, however, that personality characteristics do not necessarily equate with competencies. It is quite possible for someone to have a personality that makes them attractive as a mentee, but not the skills to make effective use of the relationship - and vice versa.

Effectiveness within the mentoring relationship, once it is established, has been related to a variety of factors. Aryee, Chay and Chew (1996) examine ingratiation behaviours in the context of mentoring. (Ingratiation in this meaning is not necessarily a negative behaviour; rather it consists of a wide spectrum of reputation management behaviours). They note the link in other studies between ingratiatory behaviours and career success. Communication skills, already identified above as a factor in the initiation stage, were recorded by Kram (1985) as a factor in relationship success for both mentors and mentees. Small field experiments carried out with coaches by myself and some colleagues suggest that the way the learner presents an issue for discussion strongly influences the nature and quality of the response. Saying 'I have a problem', for example, is likely to switch on advice mode; indicating the need for a sounding board to review thinking already partly done is likely to precipitate a more discursive, reflective dialogue.

Engstrom (Engstrom \& Mykletun, 1997) compared personality factors of mentors and mentees in the success of mentoring relationships. High scores of agreeableness, extraversion and openness to experience on the part of the mentee correlated with positive relationship outcomes, although the personality interaction between mentor and mentee was also a significant factor with respect to each of the personality dimensions.

We have not been able to find any studies which investigate the skills required in managing the mature mentoring relationship, or in managing the relationship ending from the mentee perspective. Kram (1992) (cited in Clutterbuck, 2004) refers to experiencing 'new independence and autonomy' and to the need to 'test his or her ability to function effectively without close guidance and support'. However, she does not explore how the mentee contributes towards achieving these attributes.

Managing the closure of the relationship and moving on is an important element in the satisfaction of both parties. A recent study (Clutterbuck \& Megginson, 2001) of relationship endings found that a planned, positive winding up was more effective than a gradual drifting away. It would seem logical, given that the mentee is expected to take more and more responsibility for driving the relationship, that he or she should also play a role in bringing it to a close. Kram (1983) discusses the pain of separation, 
comparing it to bereavement. Some clues to the management of the separation process may therefore be gained from the counselling literature that deals with processes for letting go.

\section{A framework of mentee competencies}

As with mentors, it seems that competencies for mentees may arise from a number of paired characteristics, which can be considered to be generic pairs of behaviours. In some cases - perhaps all these pairs are in essence probably dimensions; however, it would be presumptuous to elevate them to that status without considerable further investigation (Pascarelli, 1998). Those suggested by my analysis of the literature and by field experience in mentor and mentee training, as well as review meetings, appear to fall into three categories, relating to the mentee's stage of development and the stage of relationship development. There seem to be three pairs of competencies at (1) the relationship initiation level and four each at (2) the relationship management and (3) learning maturity/disengagement levels. Table 4 provides an overview of these competencies.

TABLE 4

A FRAMEWORK OF MENTEE COMPETENCIES (Clutterbuck \& Lane, 2005)

\begin{tabular}{lll}
\hline $\begin{array}{l}\text { Relationship } \\
\text { initiation } \\
\text { competencies }\end{array}$ & $\begin{array}{l}\text { Relationship } \\
\text { management } \\
\text { competencies }\end{array}$ & $\begin{array}{l}\text { Learning } \\
\text { maturity/disengagement } \\
\text { competencies }\end{array}$ \\
\hline Focus-proactivity & Learn-teach & $\begin{array}{l}\text { Acknowledge the debt- } \\
\text { pay it forward }\end{array}$ \\
Respect-self-respect & Challenge-be challenged & $\begin{array}{l}\text { Process awareness-process } \\
\text { management }\end{array}$ \\
& Open-questioning & $\begin{array}{l}\text { Extrinsic and intrinsic } \\
\text { feedback }\end{array}$ \\
& Prepare-reflect & $\begin{array}{l}\text { Independence- } \\
\text { interdependence }\end{array}$ \\
\hline
\end{tabular}

\section{Relationship initiation competencies}

Relationship initiation competencies include the ability to focus the relationship and being proactive, developing respect and self-respect and the ability to listen and articulate one's goals, feelings and values.

\section{Focus - proactivity}

Focus relates to having some ideas about what you want to achieve (What do you want? What do you want to become?) and/or a willingness to work with the mentor to put some clarity behind the relationship purpose.

Proactivity relates to a willingness to take initiative, to contact the mentor rather than wait to be contacted and to seek the opinion of others in determining what issues to bring to the mentor. The proactive mentee will already at least have thought about how to achieve his or her goals and ideally taken some steps towards achieving them. Mentors are also impressed by the perception of relationship commitment - behaviours that demonstrate that the mentee really wants the relationship to work and is prepared to invest in it.

\section{Respect - self-respect}

Respect and self-respect go hand in hand. Rogers' concept of mutual common regard indicates the necessity of reciprocated respect as a core constituent of rapport (1961). Mentees can demonstrate respect by showing that they value the mentor's advice and/or insights, by being attentive and by using the mentor's time and effort wisely (for example, by not making inappropriate demands).

Self-respect may be an emergent characteristic of the mentee, rather than a starting competence, but, as the research above indicates, the relationship may establish itself more easily if the mentee is relatively self-confident. There are, of course, extremes - self-confidence to the point of arrogance is unlikely to be attractive to a mentor. Equally, in community mentoring schemes, mentors often report that the greatest satisfaction comes from watching the mentee grow in self-esteem and self-confidence.

Listening - articulating

Although some mentees may not have great communication skills, the willingness to listen and to try to communicate their goals, feelings and values goes a long way towards establishing a relationship.

\section{Relationship management}

Relationship management competencies include a commitment to learning; a willingness to be challenged; being open and honest with oneself and one's mentor; and the ability to reflect on one's motives, attitude and behaviour.

\section{Learn - teach}

The mentee must have a commitment to learning and a purpose for doing so which shapes their requests of the mentor and gives the mentor a sense of direction for the relationship. They must value the learning they may acquire from the mentor and demonstrate that they do so. At the same time, they need to be aware of the mentor's needs and prepared to share their experiences, learning and insights, where these will be of interest and value to the mentor.

\section{Challenge - be challenged}

The mentee must be willing and able to engage in constructive dialogue. This requires occasional challenge - not simply accepting advice from the oracle, but delving deeper and exploring the reasoning behind advice and guidance given. At the same time, they must be open to examining issues about which they feel fearful or otherwise uncomfortable, in the cause of gaining greater understanding.

\section{Open -questioning}

Mentees must be prepared to be honest with themselves and their mentors, both providing an accurate description of issues they face and being willing to consider different perspectives and approaches. At the same time, they need the appropriate skills to pose questions to the mentor in ways that make it clear what kind of help they need at this time - a sounding board, direct advice, counselling or some combination of these.

Prepare - reflect

This could perhaps be described as reflect - reflect, for it is important that the mentee spend quiet thinking time both before the mentoring session (to prepare what they want to discuss and why) and after (to review what they have learned and extract further lessons from it). Reflection also encompasses willingness to examine one's own motives, drives, attitudes and behaviour.

\section{Advanced competencies for mentees}

The four dimensions of advanced competencies suggested by both field experience and mentoring case studies are outlined below.

\section{Acknowledge the debt - pay forward the debt}

There is a substantial difference between demonstrating gratitude and ingratiation. The level of mutual respect required in the relationship should make ingratiation untenable as a behaviour, but the mentee should be able to express their appreciation for the mentor's time and thoughtfulness. They may also be able to reciprocate in more practical ways - for example, one of my mentees keeps an eye open for public platforms I might find it commercially useful to speak at, although there is no obligation for her to do so.

Paying forward the debt is a reflection of a phenomenon noted in much of our field research. People who have been effective 
mentees frequently wish to become mentors in turn. Indeed, this is one of the core measurements of the success of a mentoring relationship or scheme. It is also a key goal for community mentoring in the UK (Miller, 2002).

Process awareness - process management

An awareness of the process is essentially a contextual competence. Field interviews suggest strongly that mentees learn more and reflect more, if they understand what the mentor is trying to do and why. Mentoring therefore becomes a collusive activity, in which the mentee takes an active role in helping the mentor help them. For example, if the mentee may recognise that a period of silence is an opportunity for them to reflect; or the may mentee craft the way an issue is presented to the mentor, in order to stimulate the kind of response that will be most useful to them (saying 'I've got a problem' is likely to trigger direct advice; saying 'I'd value your help in testing my thinking about ...' is more likely to trigger exploratory dialogue).

The process of empowerment in the mentoring relationship requires that the mentee take responsibility for the management of the process. The mature learner, or the mentee with high selfesteem and high goal clarity, may begin the relationship by setting the agenda, steering the mentor towards appropriate responses and actively drawing down upon the mentor's knowledge, experience and networks.

\section{Extrinsic and intrinsic feedback}

Receiving feedback from others can be one of the most difficult skills to learn. It demands a certain level of trust, which is not always easy to give and a willingness to accept and address one's weaknesses. People who appear self-defensive and oversensitive to criticism make it more difficult for the mentor to relax and behave naturally towards them. A relationship where one, or both sides, is constantly having to assess whether or not what they say will offend, will struggle. Indeed, it may not even get off the ground in extreme cases. As the relationship progresses, the need typically increases to accept the mentor as a critical friend and to encourage 'cruel but kind' feedback. In addition, the mentee should become more comfortable with giving honest personal feedback about the mentor's performance in their role, especially when the mentor specifically seeks it.

The mentee should also be able to move beyond feedback from others to develop his or her intrinsic feedback skills. Learning how to listen to yourself or observe yourself in action takes time. With each new area of skill, you may need to begin the process again, learning what to listen for, how to recognise positive and negative patterns and how to assess the impact of experimental changes. For example, a teenager with problems of anger control learned to watch out for the tightening of muscles that indicated he would repeat a cycle of verbal abuse followed by violence. By experimenting with different reactions to these early physical cues, he was able to learn a different set of instinctive behaviours that not only helped him control himself, but also gave him more control over the situation that threatened to cause the anger. The same principles of intrinsic feedback can be applied to almost any personal performance issue at work, from time management to giving presentations or motivating colleagues.

\section{Independence - interdependence}

Being self-motivated, self-reliant, self-resourceful and selfconfident are all elements of maturity, in life as well as in learning. The more capable the mentee is in each of these areas, the less dependent they will be on the mentor. A comment I often hear from 'mature' mentees is: 'When I was faced by a dilemma, I thought, 'how would my mentor have approached this?' and I soon had the answer'. This phenomenon of role model in absentia appears to characterise those relationships where the mentee has expanded both the scope and the portfolio of their responses to learning opportunities. Independence is likely to be accompanied by a shift from using the mentor as advisor to using him or her as sounding board. It is also likely to involve an increasing confidence in their own ability to manage their career planning and progress towards career objectives.

Developing a wide range of support resources is also a sign of learning maturity. With the mentor's help initially, and gradually through his or her own ingenuity, the mentee builds a network of advisors - sources of information, influence and encouragement - upon which he or she calls for different needs and in different circumstances. The mentee also develops the skill to sustain and enhance relationships within this network and may reciprocate to the mentor by passing on information and contacts from outside the mentor's sphere.

\section{Conclusions and implications}

The proto-competencies for mentors and mentees explored here belong to the specific context of developmental mentoring and to structured mentoring programmes. By developmental mentoring, I mean off-line relationships, where there is no expectation of sponsorship and a concentration on helping the less experienced person achieve independence. By structured programmes, I mean those where there is a process for assisting people (and in particular those who are at a racial, gender or other disadvantage) to find a suitable mentor, some training for participants to help them use the relationship well, and some form of ongoing background support for participants.

A number of writers on mentoring have linked mentor competencies with the phases of relationship development, suggesting that specific skills should be addressed as they become necessary in the management of the relationship (for example). However, none, so far as I have been able to ascertain, has applied the same principle to the development of mentee competences.

Of course, it cannot be expected of mentors and mentees to have all of these competencies. However, they can be helped in acquiring and reinforcing each of the competencies. Issues that need further explanation here include the timing and extent of help and whether it should be given by the mentor or by a source outside the relationship. With regard to timing, much will depend upon the mentee's starting point. We might expect a mentee who is mature in the sense of learning capability and who has prior experience of being mentored to begin with a much fuller competence set than one who is a neophyte in both respects. According to Yan $\mathrm{Lu}$ (2002), previous experience of a mentor-type relationship with a school teacher as a young student correlates strongly with subsequent development of positive mentoring relationships. The mentee who is low in both previous experience of mentoring and learning maturity will presumably require more support upfront and more tolerance from the mentor than someone who is high on both counts. In general, the mentee who has low learning maturity and experience of being mentored will need a wider range of support and encouragement simply to embark on the relationship.

Someone with high learning maturity and little experience in mentoring should swiftly adapt to the relationship, but many require a high degree of initial clarity about what to expect. A mentee who has low learning maturity and a lot of experience in mentoring is a less likely combination. However, we have encountered people who have had an ineffective mentoring relationship. Here the mentor may need to spend time early in the relationship building his or her credibility with the mentee.

\section{Future research recommendations}

Although all of the proposed competences described have face validity, there is still a great deal of research to be done to establish the validity using more rigorous measures. In the meantime, however, having at least a tentative framework of mentee competencies should help scheme coordinators design training that helps mentees present themselves more effectively to their mentors and engage more fully in the initiation of the relationship. It should also help to deliver mentee training more 
closely in phase with evolving needs. Finally, it should also be useful in making mentors more aware of what to expect from a mentee - and how they can work with the mentee to help them gain more from the relationship.

Given the paucity of data from desk research, a high emphasis needs to be placed on field research. The process of data gathering in the field has been in three main forms: two highly informal and subjective; one more formal and more objective. First, mentors and mentees have been asked to discuss and record those characteristics they would expect to value and those they do not value, in both roles. Typical responses include an aversion among mentees to a mentor who talks at them rather than with them; and among mentors, an aversion to people who expect too much of the relationship, people who do not respond (variously described as 'black holes' or 'puddings') and people who are unwilling to give commitment. A second phase involves review meetings, where mentors and mentees discuss their actual experiences, with a view to improving both the scheme process and their own skills in the roles. Over the past two years, I have also been gathering data on mentor and mentee expectations, behaviours and outcomes in a continuing longitudinal study. At time of writing, the data from this study are not ready for detailed statistical analysis, but they appear to support the broad thrust of the previous two phases.

From an academic perspective, I hope this analysis provides a starting point for continued research to refine the notion of mentoring competencies. Certainly, some greater clarity around which competencies are generic in all forms of mentoring would be helpful, along with a credible diagnostic process to map the micro-competencies of mentoring against the requirements of specific situations and forms of mentoring.

\section{REFERENCES}

Ackley, B. \& Gall, M.D. (1992). Skills, strategies and outcomes of successful mentor teachers. Paper presented at the Annual Meeting of the American Educational Research Association, April 20-24, San Francisco, California.

Aryee, S., Chay, Y.W. \& Chew, J. (1996). The motivation to mentor among managerial employees: An interactionist approach. Group and Organization Management, 21, 261-277.

Bandura, A. (1982). Self-efficacy mechanism in human agency. American Psychologist, 37 (2), 122-147.

Bullis, C. \& Bach, B.W. (1989). Are mentoring relationships helping organisations? An exploration of developing mentee-mentor-organisational identifications using turning point analysis. Communication Quarterly, 37, 199-213.

Clutterbuck, D. (1998). Learning alliances: Tapping into talent. London: Institute of Personnel and Development.

Clutterbuck, D. (2001). Everyone needs a mentor: fostering talent at work. London: CIPD.

Clutterbuck, D. \& Lane, G. (2005). The situational mentor. London: Gower.

Clutterbuck, D. \& Megginson, D. (1999). Mentoring executives and directors. Oxford: Butterworth-Heinemann.

Clutterbuck, D. \& Megginson, D. (2001). Winding up and winding down a mentoring relationship. Paper at the $8^{\text {th }}$ European Mentoring Centre Conference, Cambridge.

Clutterbuck, D. \& Sweeney, J. (2003). Coaching and mentoring. Burnham: Clutterbuck \& Associates.

Daniels, T.D. \& Logan, L.L. (1983). Communication in women's career development relationships. In P. Postrum (Ed.). Communication Yearbook, Vol. 7, 532-552. Beverly-Hills, CA: Sage.

Engstrom, T. \& Mykleton, R. (1997). Personality factors' impact on the success in the mentor-protege relationship. Dissertation.
Fagenson, E.A. (1992). Mentoring:who needs it? A comparison of protégés and non-proteges' needs for power achievement, affiliation, and autonomy. Journal of Vocational Behavior, 41, 48-60.

Franks, D.D. \& Marolla, J. (1976). Efficacious action and social approval as interacting dimensions of self-esteem: a tentative formulation through construct validation. Sociometry, 39, 324-341.

Goleman, D. (1996). Emotional Intelligence. London: Bloomsbury.

Hay, J. (1995). Transformational mentoring. New York: McGrawHill.

Hall, D.T. \& Kahn, W.A. (2002). Developmental relationships at work: A learning perspective. In C.L. Cooper \& R.J. Burke (Eds.). The new world of work: Challenges and opportunities, 49-74. Oxford: Blackwell.

Ibarra, H. (2000). Making partner: mentor's guide to the psychological journey. Harvard Business Review, 78 (2), March-April, 147-155.

Kahn, W.A. (1993). Caring for the caregivers: Patterns of organizational caregiving. Administrative Science Quarterly, 38 (4), 539-563.

Kalbfleisch, P.J. \& Davies, A.B. (1991). Minorities and mentoring: Managing the multicultural institution. Communication Education, 40, 226-271.

Kalbfleisch, P.J. \& Davies, A.B. (1993). An interpersonal model for participation in mentoring relationships. Western Journal of Communications, 57, 399-415.

Kiohnen, E.C. \& John, O.P. (1998). Working models of attachment: a theory based prototype approach. In J.A. Simpson \& W.S. Rhodes (Eds.). Attachment theory and close relationships. New York: Guilford Press.

Klasen, N. \& Clutterbuck, D. (2002). Implementing mentoring schemes: A practical guide to successful programs. London: Butterworth-Heinemann.

Kram, K.E. (1983). Phases of the mentoring relationship. Academy of Management Journal, 26, 608-625.

Kram, K.E. (1985). Improving the mentoring process. Training and Development Journal, 39 (4), 19-23.

Kram, K.E. (1996). A relational approach to career development. In D.T. Hall \& Associates (Eds.). The career is dead - long live the career: A relational approach to careers, 132-157. San Francisco: Jossey-Bass.

Lane, G.M. (1996). The competence of a mentor and implications for directors and CEO's. Paper to the $3^{\text {rd }}$ European Mentoring Conference, London.

Lane, G.M. (1997). The developed model of mentor competence. Paper to the $4^{\text {th }}$ European Mentoring Conference, London.

Miller, A. (2002). The way mentoring is going. Paper to the $9^{\text {th }}$ European Mentoring and Coaching Council Conference.

O'neill, R. (2001). Gender and race in mentoring relationships: a review of the literature. In D.Clutterbuck \& R. Ragins (Eds.). Mentoring and Diversity: An international perspective. Oxford: Butterworth-Heinemann.

Pascarelli, J. (1998). A four-stage mentoring model that works. In S. Goodlad (Ed.). Students as mentors and tutors. London: Kogan Page.

Ragins, B.R. (1989). Barriers to mentoring: the female manager's dilemma. Human Relations, 42 (1), 1-23.

Ragins, B.R. (1999). Mentoring in the new millennium: time to reflect, or party like it's 1999? Paper to the $6^{\text {th }}$ European Mentoring Centre Conference.

Sands, R.G., Parson, L.A., \& Duane, J. (1991). Faculty mentoring in a public university. Journal of Higher Education, 62 (2), 174-193.

Yan Lu, R. (2002). Mentoring in Belgian organisations: does theory fit practice? Paper to the $9^{\text {th }}$ European Mentoring and Coaching Council Conference. 